\title{
VOEDINGSVRAAGSTUKKE IN AFRIKA*
}

\section{Inleiding}

Die uitnodiging van die Direkteur van die Afrika-Seminaar van die P.U. vir C.H.O. om die onderwerp „Voedingsvraagstukke in Afrika" voor te dra, word van harte deur my verwelkom en as ' $n$ besondere voorreg beskou.

Ek het vroeër reeds die stelling gemaak dat die Republiek van Suid-Afrika myns insiens met twee hoofprobleme te kampe het: die rasseprobleem en die voedingsprobleem. ${ }^{1}$ ) Beide is hoofsaaklik van 'n sosio-ekonomiese aard. Die laasgenoemde probleem is maar net ' $n$ faset van die eerste en raak hoofsaaklik die voeding van die Nie-blanke bevolking. Die sterftesyfer van die Nieblankes, veral van Bantoekinders, is hoog o.a. as gevolg van onder- en wanvoeding; die volwassenes se weerstandsvermoë teen siektes is laag soos die kort lewensduurte van die Nie-blanke aandui, en groot bedrae moet gevolglik deur die Regering aan gesondheidsdienste bestee word om hierdie toestande te probeer verhelp of lenig.

Dit is dus nie onvanpas dat 'n segsman van die $\mathrm{Na}$ sionale Voedingsnavorsingsinstituut (N.Voed.N.I.) 'n bydrae in hierdie verband aan die Afrika-Seminaar lewer nie. Derhalwe my waardering vir hierdie geleentheid.

In die Republiek - en ook elders in Afrika - kan voedingsnavorsing op die duur groot diwidende afwerp, maar die voordele sal natuurlik nie noodwendig dadelik merkbaar of meetbaar wees nie. Daar moet egter sorg gedra word dat die resultate van voedingnavorsing in basiese voedingsvoorligting vertolk word. Indien die instelling van omvattende voedingsvoorligtingsdienste aan alle bevolkingsgroepe vertraag word, sal die land steeds

\footnotetext{
* Dic referent is Direkteur van die Nasionale Voedingsnavorsingsinstituut van die W.N.N.R.
} 
vrugtelose uitgawes ten opsigte van die behandeling van siektes aangaan, en onberekenbare verliese deur die afwesigheid of ondoeltreffendheid van ongestelde werkers ly. Voedingsvoorligtingsdienste moet as 'n uiters waardevolle belegging beskou word.

Wat ander Afrikastate* betref, wil ek nie 'n opinie oor hul rassevraagstukke uitspreek nie, maar dit is my mening dat voedingsprobleme hul ernstigste vraagstuk is, alhoewel dit nie noodwendig deur hul leiers as sulks herken of besef word nie.

\section{Voeding en die Staat}

Indien die volle ontwikkeling van al die natuurlike hulpbronne van die Republiek van Suid-Afrika, insluitende die menslike faktore, verkry moet word, sal die probleme verbonde aan wanvoeding en gebreksiektes aangepak en opgelos moet word. Om hierdie siektes effektief te bekamp, is 'n deeglike kennis van die oorsaaklike faktore en metodes van voorkoming nodig.

In ons hedendaagse siening dra die Staat die verantwoordelikheid om na die welsyn van elke lid van die gemeenskap om te sien, veral na dié van die swakkere vate van ons samelewing. Die voeding van die gemeenskap is een van dié aspekte ten opsigte waarvan daar 'n verpligting op die Staat rus.

Voordat die Staat egter 'n gesonde en doeltreffende voedingsbeleid in praktyk kan bring, moet hy oor 'n baie deeglike kennis van die voedingstatus van die bevolking beskik; moet hy weet waar die gebreke is; moet hy weet wat die oorsake van die gebreke is en ook die versekering hê dat enige stappe wat hy doen en openbare gelde wat hy bestee die nodige heilsame uitwerking sal hê.

Ten spyte daarvan dat die Republiek se Landbou en Nywerheid baie goed ontwikkel is en dat ons t.o.v. voedselbeskikbaarheid in 'n gunstige posisie verkeer, is dit

\footnotetext{
* In hierdie verband word meermale meer bepaald Afrikastate besuide die Sahara bedoel.
} 
egter bekend dat daar baie gebreke in die fisiese en ekonomiese aspekte van voedseldistribusie in Suid-Afrika is. Die Republiek het ongetwyfeld voedingsprobleme, maar dit beskik beslis oor die middele waarmee hierdie probleme opgelos kan word. Hierdie optimistiese stelling sou nie van toepassing wecs t.o.v. die oplos van die voedselprobleme van verskeie Afrikastate nie.

\section{Samewerking van die R.S.A. met ander Afrikastate}

Hoewel daar in dic verlede noue en hartlike samewerking tussen die Republiek en die Kommissie vir Tegniese Samewerking in Afrika besuide die Sahara (C.C. T.A.), die Wetenskaplike Raad vir Afrika besuide die Sahara (C.S.A.) en die Voedsel- en Landbouorganisasie (van die V.V.O.) bestaan het en waar die R.S.A. 'n leidende rol in hierdie verband, weens sy hoë peil van ontwikkeling op landboukundige, mediese, voedings-, behuisings- en ander tegniese gebiede, gespeel het, is ons lidmaatskap van die eerste twee organisasies reeds onmoontlik gemaak deur dic antagonistiese optrede van ander Afrikastate en dreig ook die lidmaatskap van SuidAfrika by die V.L.O. in gevaar te wees - as mens let op die insident in 1962 in Tunisie, toe die Afrikastate daarop aangedring het dat Suid-Afrika hom uit die V.L.O.-Kongres van die Afrikastreek moet onttrek.

Of die R.S.A. nou noodwendig iets daarby sal verloor deur sig wel te onttrek aan al hierdie organisasies, is te betwyfel, daar Suid-Afrika nog steeds slegs bydraes gelewer het en nog min of niks van die onontwikkelde state in Afrika terug ontvang het nie.

Ek het dit vroeïr reeds beklemtoon dat die belangrikste probleem van ander Afrikastate voedings- en voedselprobleme sal wees. Die swart leiers se (vryheids)krete van "Ochoeroe" gaan gepaard met die verdrywing van die witman uit hierdie state en die aanhitsing tot antagonisme teenoor lande soos die Republiek van Suid-Afrika. Daar word verwag dat hongersnood een van die orkane sal wees wat die saaiers van die winde van verandering in die volgende dekade in Afrika sal maai. Of die Westerse 
nasies wat tans so gereed staan met voedselgeskenke „,hand-outs" - altyd nog geneë, of in staat, sal wees om met hul vrygewigheid vol te hou, is 'n ander saak.

Wat ons wel kan glo en aanvaar is dat die Republiek van Suid-Afrika steeds een van die belangrikste voedselproduserende lande van Afrika besuide die Sahara sal wees, dat dit nog die vooraanstaande land op landbou- en nywerheidskundige en tegnologiese gebied sal wees en dat die tans antagonistiese Afrikastate mettertyd na SuidAfrika sal moet omsien om hulpmiddele en tegniese kennis.

\section{Voedingsvereistes van die mens}

Om enigsins ' $n$ insig in die voedsel- en voedingsprobleme van individue en bevolkings te kry, moet die voedingstofbehoeftes van die menslike liggaam in oënskou geneem word.

Baie beramings van die daaglikse behoeftes aan kalorieë, proteïen, vet, vitamiene en minerale is reeds deur deskundige groepe in baie lande en deur internasionale organisasies gemaak. 'n Uitgebreide bespreking hiervan sou vir die doel van hierdie referaat oorbodig wees. Ek sal dus volstaan met die jongste syfers vir slegs die basiese voedingsbehoeftes van 'n volwasse man soos gestel deur die Nasionale Voedingsraad van die Republiek in 1956:

Kalorieë - $3000 \mathrm{Kcal} /$ dag.

Proteien $-65 \mathrm{gram} / \mathrm{dag}$, waarvan een derde dierlike proteïn moet wees.

Voedselbeskikbaarheid vir menslike gebruik in Suid-Afrika

In Tabel 1 word die netto gemiddelde per capitahoeveelhede voedsel aangedui wat in 1957 vir menslike verbruik in die Republiek beskikbaar was. Hierdie voorrade sluit invoere van voedsels in en uitvoere en dierevoer uit en kan vir praktiese doeleindes as die gemiddelde voedselinname beskou word. 
Tabel 1: Voedselvoorrade vir menselike gebruik in Suid-Afrika, 1957

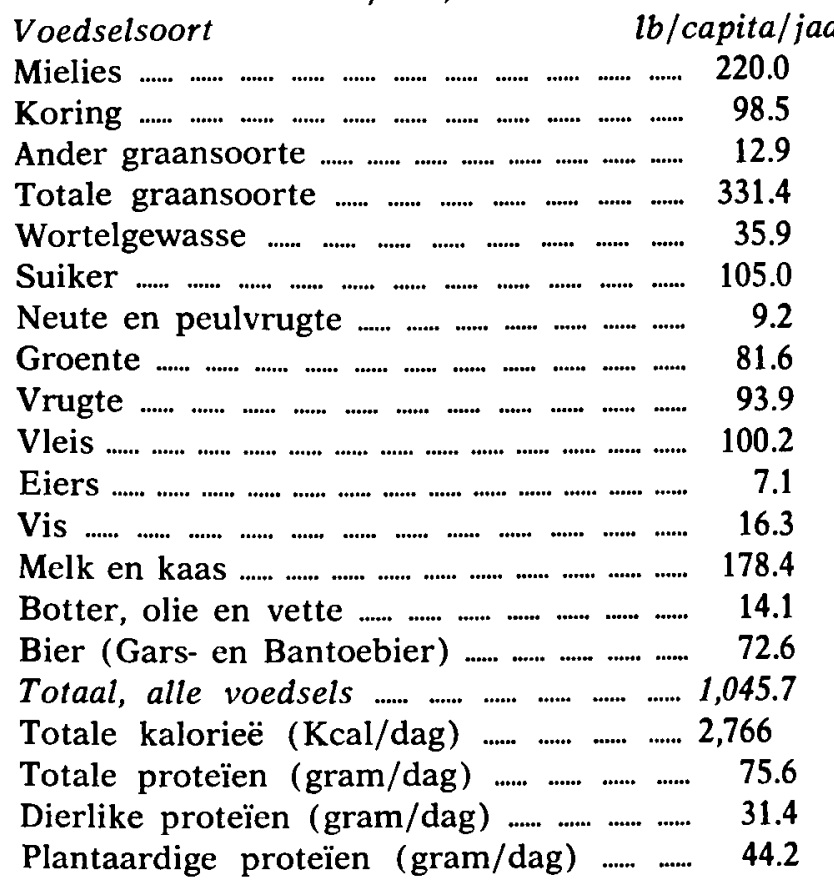

Bron: Voedselbalansstate: Departement van Landbou-ekonomie en -bemarking.

Kortliks kan van hierdie gegewens afgelei word dat die gemiddelde Suid-Afrikaner (d.i. man, vrou en kind van alle rasse) ongeveer 'n 1/2 ton voedsel per jaar eet, waarvan graanvoedsel ongeveer een derde uitmaak. Ook eet hierdie hipotetiese Suid-Afrikaner ongeveer 'n 100 lb. elk van suiker, vrugte en vleis. Sy daaglikse voedselinname bedra 2,766 kalorieë en sluit 31 gram dierlike proteien in.

In een van die jongste publikasies van die V.L.O. ${ }^{2}$ ) word die gemiddelde daaglikse per capita-voedselinname gedurende 1960 van die lande van die wêreld in drie kategorieë t.o.v. kalorieë en dierlike proteïen ingedeel, nl.:

Kalorieë:

(a) Meer as 2,700 kalorieë; 
(b) 2.200 tot 2,700 kalorieë;

(c) Minder as 2,200 kalorieë.

Dierlike proteïen:

(a) Meer as 30 gram;

(b) 15 tot 30 gram;

(c) Minder as 15 gram.

Volgens die syfers verstrek in Tabel 1 sou die Republiek dus in beide gevalle onder die gunstigste kategorieë ressorteer. Volgens die V.V.O.-publikasie word in SuidAfrika egter t.o.v. kalorieë in die tweede groep, nl. 2,200 tot 2,700 kalorieë, geplaas.

\section{Voedselproduksie van die R.S.A.}

Soos reeds vermeld, beklee die Republiek van SuidAfrika t.o.v. voedselproduksie 'n baie gunstige posisie wanneer dit met ander state in Afrika besuide die Sahara vergelyk word. Ten spyte daarvan dat die Republiek slegs 7 persent van die totale landsoppervlakte van hierdie kontinent besuide die Sahara beslaan, nl. 472,494 vk. myl, en slegs 10 persent van die totale bevolking van hierdie area dra, nl. 15 miljoen, lewer dit nogtans ongeveer 25 persent van die totale hoeveelheid voedsel wat in hierdie gebied geproduseer word, nl. 15 miljoen ton, waarvan ' $n$ groot gedeelte, hoofsaaklik in die vorm van mielies, uitgevoer word.

Wat is die posisie van ander Afrikastate en van ander lande van die wêreld? Besonderhede van voedselproduksie van ander Afrikastate is nie beskikbaar nie en moet na ander gegewens vir so 'n vergelyking omgesien word, bv. ekonomiese data en bevolkingsyfers.

In Tabel 2 word die verspreiding van die wêreldbevolking en -inkomste in 1956 volgens ,kontinente" aangedui:

Tabel 2: Streeksverspreiding van die wêreldbevolking en -inkomste (1956)

Noord-Amerika

$\%$-asie van totale bevolking

Europa $\%$-asie van totale inkomste 


$\begin{array}{lrr}\text { Oseanië } & 0.5 & 1.5 \\ \text { Sentraal en S.-Amerika } & 6.8 & 4.7 \\ \text { Nabye Ooste } & 4.4 & 1.8 \\ \text { Afrika } & 7.1 & 2.2 \\ \text { Verre Ooste } & 52.3 & 12.3 \\ \left.\text { Bron: V.L.O. }-1962^{3}\right) & & \end{array}$

Tabel 2 dui aan dat Afrika, gesien teen sy huidige bevolking, ekonomies skraal bedeeld is en dat slegs die Verre Ooste swakker daaraan toe is.

Wat dan is die toekomsvooruitsigte van die wêreld in die algemeen en Afrika in die besonder? Die V.V.O. se bevolkingsberamings vir die jaar 2000 word in Tabel 3 verstrek: ${ }^{4}$ )

Tabel 3: Beraamde bevolking van die wêreld (in milj.)

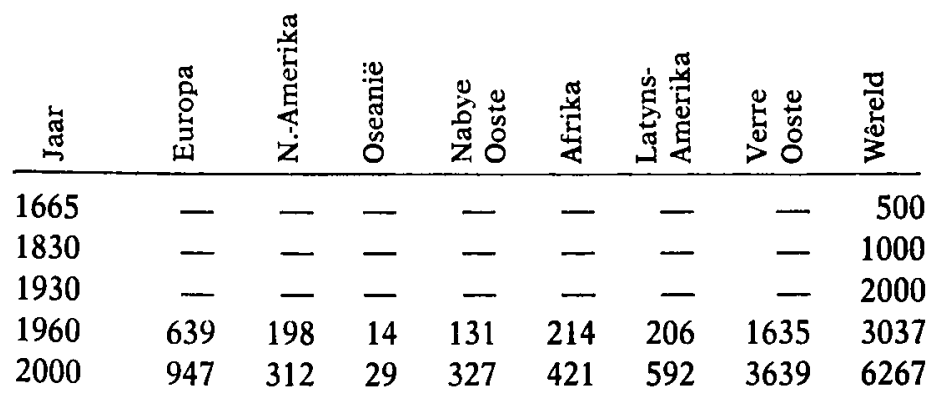

Die wêreldbevolking, wat ongeveer 1,000 miljoen in 1830 getel het, het in 100 jaar verdubbel na ongeveer 2,000 miljoen; daarna het dit slegs dertig jaar geneem om met 'n verdere 1,000 miljoen aan te was na 3,000 miljoen, 'n getal wat na beraming aan die einde van hierdie eeu weer sal verdubbel tot oor 6,000 miljoen!

En Afrika? Volgens beramings sal Afrika se bevolking van 214 miljoen in 1960 tot 421 in die jaar 2000 aanwas - ook ongeveer 'n verdubbeling in getal.

Die Swart „Uitlanders” in die Republiek

In 'n bespreking van voedingsvraagstukke in Afrika, is dit nie onvanpas om na die "uitheemse" swartman 
binne die landsgrense van Suid-Afrika te verwys nie. Dit word bereken dat daar ongeveer een miljoen swart uitlanders in die Republiek woonagtig is, van wie ongeveer 400,000 as mynarbeiders diens doen.

Ek het vroeër al aangedui hoe ruim, volwaardig en gebalanseerd in die voedingsbehoeftes van hierdie mynarbeiders voorsien word. ${ }^{2}$ ) Volgens beskikbare gegewens was hul gemiddelde inname in 1959 soos volg:

Kalorië

Totale proteïen

Dierlike proteïen

Plantaardige proteïen

Dit kan dus sonder twyfel beweer word dat hulle onder die besgevoede groep ter wêreld gereken kan word en sekerlik die besgevoede groep „Bantoes" in Afrika daarstel.

Dit is dan ook interessant om op hul lande van herkoms te let. (Sien Tabel 4).

Tabel 4: Getal en herkoms van mynarbeiders deur „Wenela"* in diens geneem (op 31 Desember 1962)

\begin{tabular}{|c|c|c|c|}
\hline Suid-Afrika & $\begin{array}{c}\text { Goudmyne } \\
143,816\end{array}$ & $\begin{array}{c}\text { Steenkoolmyne } \\
12,661\end{array}$ & $\begin{array}{r}\text { Totaal } \\
156,477\end{array}$ \\
\hline Basoetoeland & 52,255 & 5,935 & 58,190 \\
\hline Betsjoeanaland & 14,980 & 40 & 15,020 \\
\hline Swaziland & 6,925 & 140 & 7,065 \\
\hline Ooskus** & 84,886 & 14,242 & 99,128 \\
\hline Trope $e^{\star \star \star}$ & 68,411 & 104 & 68,515 \\
\hline Totaal & 371,273 & 33,122 & 404,395 \\
\hline
\end{tabular}

Daar is vasgestel dat hierdie mynarbeiders, as gevolg van 'n behoorlike dieet en die gereëlde verrigting van fisiese arbeid, altyd in gewig toeneem en dat daar 'n ge-

* „Witwatersrand Native Labour Association": Offisiële Korrespondensie, April 1963.

** Hoofsaaklik Mosambiek.

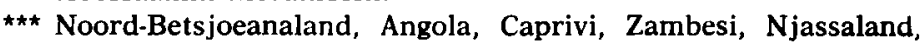
Tanganjika, Pafuri. 
middelde toename in gewig van $122 \mathrm{lb}$., met rekrutering, tot $128 \mathrm{lb}$., na een maand, voorkom. ${ }^{4}$ )

'n Verdere afleiding wat t.o.v. hierdie opnames ge. maak is, is dat die aanvanklike gewig van die mynrekrute bepaal word deur die jaar en die tyd van die jaar waarin hulle by die myne aankom en derhalwe deur die voedingspeil van hul tuisomgewing. ${ }^{5}$ )

Dit is dus duidelik waarom die mynbedryf in SuidAfrika geen probleme ondervind om honderd-duisende mynwerkers uit ander Afrikastate te trek nie.

\section{Gebreksiektes}

Kwashiorkor ('n proteïengebreksiekte by kinders) en ander gebrek- en verwante siektes soos marasmus ('n kindersiekte veroorsaak deur 'n gebrek aan alle nutriënte, uithongering), ragitis ('n vitamien D-gebrek), pellagra ('n nikotiensuur-gebrek), gastro-enteritis, pneumonie en tuberkulose kom hoofsaaklik onder Nie-blankes in SuidAfrika voor. Onder volwasse Bantoes kom hoofsaaklik pellagra voor. Die meeste gebreksiektes onder die Bantoes kan moontlik teruggevoer word na die hoë inname van mielieprodukte met die dieet, sonder aanvulling van "beskermende" voedsels wat die nodige hoeveelhede hoi kwaliteit-proteïen en genoegsame vitamiene en minerale bevat.

Veldwerkers van die N.Voed.N.I. vermoed ook dat daar aanduidings van vitamien C-tekorte onder Blanke kinclers in die dorre Wes-Kaaplandse gebiede bestaan.

\section{Kwashiorkor}

Die ernstigste voedingsprobleem waarmee Suid-Afrika tans te doen het is kwashiorkor, wat hoofsaaklik onder Bantoebabas en -kleuters van die ouderdom 6 maande tot 5 jaar voorkom. Van 8 tot 25 persent van alle Nieblanke kinders wat in die groot hospitale van Pretoria, Johannesburg en Durban opgeneem word, ly aan hierdie siekte.

Kwashiorkor ontstaan hoofsaaklik as gevolg van 'n tekort aan proteïene in die dieet en kom in al die tegnies. 
onderontwikkelde gebiede van die wêreld voor, insluitende dele van Afrika, die Vere Ooste, Suid-Amerikaanse State, Meksiko en ook sekere Europese lande soos Griekeland, Italië en Turkye.

In die akute fase van die siekte wissel die sterftesyfer van 15 tot 60 persent in die verskeie wêrelddele. As die behandeling verkeerd is, sterf 100 persent van hierdie kinders. In die N.Voed.N.I. se Voedingskliniek vir Kinders by die Algemene Hospitaal van Pretoria is die sterftesyfer ongeveer 15 persent. Afgesien van die hoë sterftesyfer meen sommige deskundiges dat kwashiorkor, wat gewyt kan word aan 'n onvolwaardige dieet tydens die kinderjare, ook nog skadelike nagevolge in die latere lewe van sulke kinders mag hêे.

Die fundamentele kliniese en ander tekens van kwashiorkor is:

(a) vertraagde groei;

(b) veranderings in vel- en haarpigmentasie;

(c) watersug;

(d) vet-infiltrasie van die lewer;

(e) 'n hoë sterftesyfer as voldoende en goeie kwaliteit-proteïen nie in die dieet verskaf word nie.

In Augustus 1962 het die Minister van Gesondheid kwashiorkor tot aanmeldbare siekte in Suid-Afrika verklaar. Ek vermoed dat die Republiek die eerste land ter wêreld is wat hierdie nie-aansteeklike siekte as aanmeldbaar geklassifiseer het. Nou is voedingsoutoriteite en die owerhede in staat om die insidensie van hierdie siekte na reg te beoordeel en om die nodige voorsorgmaatreëls te tref om dit te bekamp en - ons hoop en vertrou - uit te wis.

Die aangemelde kwashiorkorgevalle van die Republiek vir die ses maande November 1962 tot April 1963 word in Tabel 5 verstrek.

Tabel 5: Kwashiorkorgevalle in die Republiek: November 1962-April 1963

Mnd. Prov. Blank Bantoe Kleurl. Asiaat Tot. $\begin{array}{lllllll}11 / 62 & \text { Transvaal } & 1 & 353 & 3 & 0 & 357\end{array}$

$\begin{array}{llllll}12 / 62 & 0 & 443 & 21 & 0 & 464\end{array}$




\begin{tabular}{|c|c|c|c|c|c|c|}
\hline $1 / 63$ & & 2 & 506 & 1 & 0 & 509 \\
\hline $2 / 63$ & & 1 & 413 & 3 & 0 & 417 \\
\hline $3 / 63$ & & 0 & 547 & 5 & 0 & 552 \\
\hline $4 / 63$ & & 0 & 343 & 1 & 0 & 344 \\
\hline $11 / 62$ & Kaap & 0 & 246 & 39 & 0 & 285 \\
\hline $12 / 62$ & & 1 & 323 & 47 & 0 & 371 \\
\hline $1 / 63$ & & 0 & 446 & 31 & 0 & 477 \\
\hline $2 / 63$ & & 0 & 524 & 71 & 0 & 595 \\
\hline $3 / 63$ & & 0 & 435 & 46 & 0 & 481 \\
\hline $4 / 63$ & & 0 & 422 & 24 & 0 & 446 \\
\hline $11 / 62$ & O.V.S. & 0 & 0 & 0 & 0 & 0 \\
\hline $12 / 62$ & & 0 & 28 & 1 & 0 & 29 \\
\hline $1 / 63$ & & 0 & 61 & 0 & 0 & $\$ 1$ \\
\hline $2 / 63$ & & 0 & 57 & 0 & 0 & 57 \\
\hline $3 / 63$ & & 0 & 62 & 0 & 0 & 62 \\
\hline $4 / 63$ & & 0 & 34 & 0 & 0 & 34 \\
\hline $11 / 62$ & Natal & 0 & 230 & 0 & 0 & 230 \\
\hline $12 / 62$ & & 0 & 611 & 0 & 0 & 611 \\
\hline $1 / 63$ & & 0 & 569 & 0 & 0 & 569 \\
\hline $2 / 63$ & & 0 & 840 & 1 & 3 & 844 \\
\hline $3 / 63$ & & 0 & 487 & 4 & 4 & 495 \\
\hline $4 / 63$ & & 1 & 412 & 1 & 4 & 418 \\
\hline $11 / 62$ & Republiek & 1 & 829 & 42 & 0 & 872 \\
\hline $12 / 62$ & (totaal) & 1 & 1405 & 69 & 0 & 1475 \\
\hline $1 / 63$ & & 2 & 1582 & 32 & 0 & 1616 \\
\hline $2 / 63$ & & 1 & 1834 & 75 & 3 & 1913 \\
\hline $3 / 63$ & & 0 & 1531 & 55 & 4 & 1590 \\
\hline $4 / 63$ & & 1 & 1211 & 26 & 4 & 1242 \\
\hline Totaal & vir 6 maande & 6 & 8392 & 299 & 11 & 8708 \\
\hline
\end{tabular}

Bron: Departement van Gesondheid: Offisiële Korrespondensie, Mei 1963.

Om nou ' $n$ benaderde insidensie van kwashiorkor onder die verskillende bevolkingsgroepe van Suid-Afrika te bepaal, word die volgende aannames gemaak:
(a) dat die siekte slegs by kinders tussen die ouderdom 1 tot 5 jaar voorkom;
(b) dat die getal kinders in die Republiek van die ouder- 
dom 0 tot 4 jaar gelyk is aan die getal kinders 1 tot 5 jaar oud;

(c) dat die getal kinders van dic ouderdom 1 tot 5 jaar in September 1960 (sensusmaand) gelyk is aan die getal kinders van dieselfde ouderdomsgroepe in November 1962-April 1963;

(d) dat die getal kwashiorkorgevalle vir een jaar gelyk is aan twee maal die getal gevalle vir die ses maande November 1962-April 1963.

Die beskikbare gegewens word in Tabel 6 saamgevat:

Tabel 6: Insidensie van kwashiorkor in Suid-Afrika (1962/1963)

Get. kinders

Blank Bantoe Kleurl. Asiaat Totaal

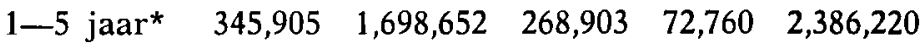

Getal kwashior-

$\begin{array}{llllll}\text { korgevalle } & 12 & 16,784 & 598 & 22 & 17,416\end{array}$

Insidensie per

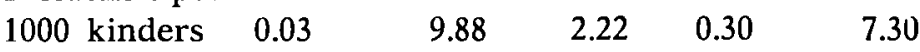

* In werklikheid $0 \_4$ jaar.

Dit is duidelik dat kwashiorkor hoofsaaklik by die Bantoe voorkom, en die gegewens verstrek in Tabel 6 laat die afleiding toe dat - in vergelyking met die lae insidensie by die Asiaat - dit nie slegs ongunstige sosioekonomiese faktore is wat hierdie siektetoestand op die Bantoe afdwing nie. Dit wil voorkom of onkunde en/of gebrekkige „ouerskap" by die Bantoe - en in 'n mindere mate by die Kleurling - ook 'n verantwoordelike rol speel.

Aanvullend tot voorafgaande gegewens kan gemeld word dat die sterftesyfers van kinders van $1-4$ jaar onder blankes in Suid-Afrika minder as 2 per 1000 kinders is, 9 per 1000 vir Asiate, 23 vir Kleurlinge en 50 vir stedelike Bantoekinders.

\section{Sosio-Ekonomiese en ander oorsake van gobreksiektes (veral Kwashiorkor)}

Dit is baie duidelik dat nie alleen nutrisionele faktore 
gemoeid is met die hoë insidensie van kwashiorkor in Suid-Afrika nie. Sosio-ekonomiese en ander faktore is duidelik daarby betrokke, en sommige hiervan sal nou behandel word. Aspekte wat hier angeteken word, sou ook op ander Afrikastate van toepassing wees.

(a) Higiëne: Die hoë sterftesyfer by babas en kleuters kan nie slegs aan wanvoeding toegeskrywe word nie. Dr. W. R. Aykroyd (1961) stel dit soos volg: „... the predominant factor in high infant mortality rates is dirt, the term being used to denote insanitary conditions generally, rather than faulty and insufficient diet. More significant is the death rate in children aged $1-4$ years; there is a good deal of evidence that a high death rate in this age period is closely associated with malnutrition..." Hy kom tot die gevolgtrekking dat die oorsake van wanvoeding ingewikkeld en ineengestrengeld is en noem o.a. armoede, beperkte voedselvoorrade, tekort aan melk, infeksie, parasiete en kulturele en sosiale faktore.

Robertson, Hansen en Moodie (1960) doen verslag oor die probleem van gastro-enteritis in voorskoolse kinders en suiglinge, veral onder Kleurlinge en Bantoes: "The relationship of malnutrition to gastro-enteritis has been shown. It is in the main the child that is suffering from malnutrition that becomes a victim, and a vicious circle is frequently set up, worse malnutrition following each repeated attack of gastro-enteritis, leading finally to kwashiorkor or death... social and nutritional factore (are) responsible for this state of affairs..."

J. Goddard (1960) benadruk dat Bantoemoeders in Durban 'n onverskilligheid teenoor die voeding, higiëne, gesondheid en welsyn van hul babas openbaar wat volgens blanke maatstawwe as niks minder as skokkend beskrywe kan word nie.!)

(b) Lae morele standaarde van die Bantoe: In hierdie verband wil ek verwys na 'n verslag van die mediese beampte van Durban, dr. G. D. English, t.o.v. nuwe gevalle van kwashiorkor in Desember 1959 en Januarie 1960. Die aantal gevalle wat ondersoek is het 364 bedra, waarvan 307 ( 84 persent) van buite Durban ,ingevoer" is en 218 
(60 persent) buite-egtelike kinders was. Dr. English sluit sy verslag soos volg af: „The provision of improved housing conclitions, the abolition of slums and an improvement in the scale of wages will all help (to combat kwashiorkor) certainly - in fact any factor which furnishes a settled family life in the Bantu community will assist. But one factor must never be overlooked. It is the need of the Bantu themselves to recognise the value of the high moral standards and to make an attempt to live up to such standards. When these people have learnt to cultivate an inner power aimed towards spiritual and moral upliftment, great progress will have been made towards the solution of the kwashiorkor problem". ${ }^{1}$ )

Die lae morele peil van die Bantoe, veral in en om die groter stedelike komplekse, is enersyds te wyte aan sy miskenning van stambeheer en andersyds sy onwillig. heid of onvermoë om blanke maatstawwe van sosiale gedrag te aanvaar.

(c) Probleme t.o.v. die egalige verspreiding van voedsels: Weens die heterogeniteit van die Suid-Afrikaanse bevolking (nie alleen t.o.v. rassegroepe nie maar ook t.o.v. streeksverskille tussen stedelike en landelike bevolking, en ook seisoenvariasie t.o.v. beskikbare voorrade, veral in die Bantoctuislande) is dit wenslik om hier die sterkste nadruk te lê op die feit dat die gemiddelde voorrade per capita nie van toepassing is op enige bepaalde seksie van die bevolking nie, maar slegs aandui hoeveel voedsel vir elke persoon beskikbaar sou wees as die verspreiding daarvan cweredig was.

Bowendien, gegewens t.o.v. gemiddelde per capitabeskikbaarheid gee geen aanduiding van moontlike seisoenskommelinge in voorrade in bv. die Bantoetuislande, of dic besondere behoeftes van sekere groepe, bv. melk vir kleuters en kinders nie.

(d) Verstedeliking van die Bantoe: Die vinnige naoorlogse ontplooiing van die nywerheidswese van SuidAfrika en die gevolglik versnelde verstedeliking van veral die Bantoe, het grootliks tot die onbestendigheid van sy 
huislike lewe bygedra. Dat hierdie faktor 'n groot invloed op die voeding van die Bantockinders het, is nie te betwyfel nie.

Dit word nie algemeen besef hoe dramaties hierdie verstedeliking - gesien teen dic veel stadiger ontwikkeling elders in Afrika - in die Republick plaasgevind het nie. Die gegewens vervat in Tabel 7 dui die verstedeliking van die "Bantoe" in Afrikastate besuide die Sahara in 1957 aan. Die tempo daarvan in die Republiek het nog geensins afgeneem nie, en die verstedeliking veroorsaak 'n ontwrigting van die Bantoe se huislike lewe, wat altyd die kind sal skaad.

Tabel 7: Verdeling van Bantoebevolkings in Afrikastale besuide die Sahara (1957)

$\begin{array}{lrr}\text { Land } & \text { Plattelands } & \text { Stedelik } \\ \text { Angola } & 3,700,000 & 10,000 \\ \text { Betsjoeanaland } & 300,000 & - \\ \text { Basoctocland } & 564,000 & - \\ \text { Kongo Republiek } & 11,100,000 & 35,000 \\ \text { Kenia } & 5,200,000 & 20,000 \\ \text { Mosambiek } & 5,000,000 & 10,000 \\ \text { Federasie (Rhodesië) } & 6,100,000 & 13,000 \\ \text { Swaziland } & 181,000 & - \\ \text { Tanganjika } & 7,450,000 & 8,000 \\ \text { Uganda } & 5,000,000 & 15,000 \\ \text { Ruanda Urundi } & 4,000,000 & - \\ \text { R.S.A. } & 8,200,000 & 1,550,000\end{array}$

Bron: „Industrial Review”, Maart 1958.

(e) Gebrek aan voorsiening en sorgsaamheid by die Bantoe: Die hele kwessie van die verbetering van die sosio-ekonomiese en voedingstoestande van die Bantoe moet nugter en rasioneel gesien word. Elke jaar na die winter en voor die eerste landsreëns geval het, is die Republiek se dagblaaie vol van verhale oor wanvoeding en gebrekstoestande onder die Bantoe. Daar is min verskil of die oes van die vorige seisoen goed was of misluk het - die Bantoe gaan die lente in met ontoereikende 
middele omdat hy nie vir hierdie maer periode voorsiening gemaak het nie.

Dr. A. R. P. Walker (1960) stel dit soos volg: „I would ... urge the necessity ... to inculcate in the Bantu an increased sense of providence and self-reliance. There are various measures for the betterment of these people which are proceeding by State and the community there are, for example, improved medical services, preventive inoculations, better housing in urban areas, the subsidization of essential foodstuffs, etc... I must stress that all our efforts designed to ameliorate the unsatisfactory aspects of the Bantu health picture will fail to achieve maximum results until we are able to educate the Bantu in nutrition and hygiene matters, and until we are able to get them to be more self-reliant and provident".

(f) Onkunde by die Bantoe: Ek kwoteer in hierdie verband weer graag vir dr. Walker: „... our Bantu, nutritionally, are more favourably placed than most other backward populations. There is much evidence, direct and indirect... to... support this view. It is possible to be well and to keep well on very simple diets providing they contain the dietary essentials - and these need not be as expensive as is usually thought to be the case. But in many reports - from Africa, India and the Far East, again and again it is stated that the problem of kwashiorkor would be far less acute if only the backward populations were able to make intelligent use of the food materials already at hand - in other words, often times it is ignorance rather than poverty that carries chief responsibility". 1 )

(g) Bygelowe en gewoontes van die Bantoe: Dit is interessant om daarop te let dat die bygelowe t.o.v. voeding en dieetgewoontes by die Bantoe in tie Republiek en elders in Afrika 'n ongunstige uitwerking op veral die verwagtende moeder, die suigeling en die jong kind het. Enkele bygelowe word hier genoem:

(i) 'n Baba mag nie die eerste vyf dae of totdat die naelstring afgeval het moedersmelk drink nie. (In hierdie 
kritieke periode word dun papwatertjies ingedwing!) (Suid- en Sentraal-Afrika).

(ii) Kinders mag nie eiers eet nie. (Die eier besit die waardevolste proteïen van alle voedsels!) (SentraalAfrika).

(iii) Eiers maak dogters onvrugbaar (Sentraal-Afri ka). (In Swaziland egter mag adolessente dogters nie eiers eet nie omdat hulle dan "seksbewus" sal word).

(iv) 'n Vrou mag nie bokvleis eet nie, want sy sal dan 'n baard kry. (Bokke is die algemeenste veesoort by die Bantoe) (Noord-Transvaal).

(v) 'n Vrou mag nie hoendervleis eet nie, want sy sal dan kraai. (Hoenders is algemeenste huisdier by die by die Bantoe) (Noord-Transvaal). land).

(vi) Vars meld veroorsaak ingewandswurms (Swazi-

(vii) 'n Baba word 'n dermspoeling (enema) toegedien 'n paar uur na geboorte; dit word daagliks herhaal totdat die kind ongeveer twee jaar oud is (Swaziland).

(viii) Die sterkste kind van 'n tweeling word uitgehonger tot die dood toe en slegs die swakste kind word gevoed en versorg (Vendaland).

(ix) Groente word as geskik as voedsel slegs vir vroue en kinders beskou, maar nie vir mans nie (Swaziland).

(x) Afgeroomde melk is waardeloos of skadelik (Swaziland).

(xi) Swanger vrouens mag nie lewer of niertjies eet nie, want dit sal kaalkoppigheid by die kind veroorsaak (Swaziland).

(xii) Swanger vrouens mag nie heuning eet nie, want dit sal blindheid by die kind veroorsaak (Swaziland).

(xiii) Afkeer vir vis by meeste plattelandse Bantoes (Suid-Afrika).

(xiv) Vrugtebome mag nie om strooise geplant word nie, want die strooise moet gesien kan word (Swaziland). 


\section{Tcenmaatreëls teen gebrekstoestande in Suid-Afrika}

Die volgende teenmaatreëls is reeds lank in werking in die Republiek:

(a) Voedselsubsidiëring: Dic Staat bestee jaarliks ongeveer R30 miljoen aan die subsidiëring van stapelvoedsels (hoofsaaklik aan mielie-, koring- en suiwelprodukte).

Dit is bekend dat die sosio-ekonomiese status van 'n groot deel van die Nie-blanke bevolking baie laag is. $\mathrm{Om}$ hierdie rede is die verlaging van pryse van sekere voedsels deur subsidiëring soos deur die Staat toegepas word, 'n lofwaardige maatreël. Die moontlikheid om die omvang en die mate van subsidiëring uit te brei, te wysig, aan te pas en selfs te vergroot moet oorweeg word, in besonder in die geval van voedsels soos melk en melkpoeier, vleis, bruin brood gebak van meel met 'n hoë uitmalingsgraad en ongesifte mieliemeel.

Die Eerste Minister se Ekonomiese Adviesraad het in Julie 1960 soos volg gerapporteer: „Gelyktydig met 'n verhoging van lone moet die verbetering van die voeding van die Bantoe ook oorweeg word".

(b) Gesondheids- en maatskaplike welsynsdienste: Ongeveer R120 miljoen word jaarliks deur die Staats-, provinsiale en plaaslike owerhede en welsynsorganisasies aan gesondheids- en welsynsdienste bestee. (Daar is be raam dat twee derdes van hierdie bedrag aan dienste vir die Nie-blanke bestee word). ${ }^{6}$ )

Daar bestaan in die Republiek meer as 700 hospitale, klinieke, sendinghospitale en distriksverplegingsdienste, 280 waarvan in die platteland geleë is. (Dit word gereken dat hierdie aantal inrigtings meer is as dié wat in die res van Afrika besuide die Sahara gevind word).

Daar is 2,060 goedgekeurde vrywillige welsynsorganisasies in die Republiek geregistreer, die oorgrote meerderheid daarvan onder Nie-blankes werksaam is.

Ek is die mening toegedaan dat geen Bantoetuisland in baie jare tot sodanige peil sal kan ontwikkel om oor die nodige finansiële en tegniese middele te beskik on 
sy eie medici, verpleegsters, hospitale, welsyns- en voedingsdienste te kan daarstel nie, en dat hulle in hierdie verband ten minste nog 'n dekade of langer op die R.S.A. aangewese sal wees.

(c) Ontwikkeling van Bantoe-landbou: Die Departemente Bantoesake, Landbou en Bosbou het jarelank reeds intensief aandag gegee aan die uitbreiding en verbetering van die landbou- en bosboupotensiaal van die Bantoetuislande. Spesiale afdelings van die Departement Bantoeadministrasie en -ontwikkeling spits hulle tans op steeds toenemende skaal hierop toe. (Die werk in hierdie verband sou op sigself 'n bydrae aan die Afrika-Seminaar regverdig en word nie hier in detail behandel nie).

Voedingdeskundiges sou veral pleit dat die produksie van melk en vleis in of vir gebiede met hoë Nie-blanke bevolkings so kragdadig moontlik aangemoedig moet word.

Die volgende maatreëls is in die jongste jare getref:

(a) Melkpocierverspreidingskema: In die afgelope drie jaar is ' $n$ staatsgesteunde melkpoeierverspreidingskema deur die Departement van Gesondheid in werking gestel om hoofsaaklik kwashiorkor te bekamp. Die skema is so suksesvol gevind in die land se groter stede, dat dit elke jaar steeds verder uitgebrei is. Oorweging word tans daaraan geskenk om alle plaaslike owerheidsgebiede waar kwashiorkor voorkom ook onder dié skema in te skakel.

Onder die skema word afgeroomde melkpoeier deur die Suiwelraad teen die besonder lae (gesubsidieerde) prys van $15 \mathrm{c}$ per $\mathrm{lb}$. in $1 \mathrm{lb}$.-verpakkings aangebied. Die Staat maak dan ' $n$ bydrae van $5 \mathrm{c}$ per $1 \mathrm{~b}$. asook die plaaslike owerheid en die moeder moet dan - indien sy kan - ook 'n bydrac van $5 \mathrm{c}$ per lb. maak.

'n Pond poeier word weekliks per kind by kliniekc onder die skema uitgereik. Die kind moet ongeveer 2 onse ( 2 opgehoopte eetlepels) per dag - wat gelykstaan aan een pint melk per dag - met sy ander voedsel in- 
neem: sodanige rantsoen verskaf vir 'n kind 'n genoegsame hoeveelheid proteïen van hoë gehalte.

(b) Kwashiorkor as aanmeldbare siekte: Soos reeds vroeër gemeld, is kwashiorkor tot aanmeldbare siekte in Augustus 1962 deur staatswetgewing verklaar. Hierdie is ' $n$ uiters waardevolle bydrae tot die bekamping van hierdie siekte.

(c) Voedseltegnologiese navorsing: Staatsgesteunde inrigtings, veral die N.Voed.N.I. van die W.N.N.R., ondersoek alle moontlike metodes om goedkoop, maar voedsame, voedsels te produseer.

Die moontlikheid van die gebruik van vismeelblom en ander vorms van vis vir suigling- en kindervoeding word steeds ondersoek. Die ontwikkeling van geskikte sojavoedsels word ook bestudeer. Die soektog na ander proteïenvoedsels van hoë kwaliteit duur voort, in besonder met betrekking tot die peulgewasse wat blykbaar grootliks van mekaar in proteïenkwaliteit verskil. Die waarde van gemengde groentes en ander graansoorte, bv. bokwiet, as aanvullende voedsels, geniet verder ook aan dag.

Die verhoging van die produksie en die voedings. waarde van die afgeroomde melkpoeier in Suid-Afrika word deur die N.Voed.N.I. aanbeveel, asook 'n ondersoek na die moontlikheid om ten volle of gedeeltelik die vitamiene $A$ en $D$ terug te plaas wat met die afroom van melk verwyder word. Die vervaardiging van sowel geste. riliseerde melk as afgeroomde melkpoeier vir gebruik in gebiede waar die voorrade van vars melk onvoldoende is, verg ook ondersoek.

'n Intensiewe studie word vereis van die beste toestande waaronder mielies as voedsel vir die mens gebruik kan word, aangesien mielies veral in die landelike gebiede die stapelvoedsel van die Nie-blanke bevolking is. (Laasgenoemde onderwerp is uiters ingewikkeld en breed en kan nie in besonderhede hier behandel word nie, maar laat my toe om te meld dat ons rede het om te glo dat groenmieliemeel moontlik 'n beter voedsel sal wees as meel van ryp mielies vervaardig). 
Op grond van verkreë inligting kan voedsel- en voedingsprogramme uitgewerk en deur die Staat onderneem word wanneer voldoende bewyse ter regverdiging daarvan beskikbaar is. Van tyd tot tyd moet bevestig kan word of sulke skemas tot die voordeel van die land is, al dan nie. (Sien bogenoemde melkpoeierverspreidingskema).

(d) Kliniese navorsing oor gebreksiektes: Die $\mathrm{N}$. Voed.N.I. en ander W.N.N.R.-gesteunde mediese navorsingseenhede en -groepe doen aktief navorsing in verband met voedingsgebreksiektes. Die N.Voed.N.I. beskik oor twee voedingsklinieke: een vir kinders en een vir volwassenes, beide waarvan uitsluitlik vir Bantoes ingestel is.

Die werk wat in Suid-Afrika in hierdie verband gedoen word, geniet wêreldwye belangstelling en morele steun.

Verdere maatreëls wat ingestel of uitgebrei behoort te word:

(a) Voedingspeilopnames: Alhoewel in die N.Voed. N.I. navorsing verrig word oor voedingspeilopnames, behoort sodanige opnames van owerheidsweë intensief onderneem te word om 'n geheelbeeld van voedingstoestande onder alle bevolkings- en streeksgroepe in die land te verkry.

Dit is interessant om hier te meld dat die TomlinsonKommissie soos volg oor voeding in die Bantoetuislande gerapporteer het: „Die Kommissie het dit nie moontlik gevind om die belangrike saak van voeding in die Bantoegebiede te ondersoek nie, maar wil aanbeveel dat die betrokke instansies dit so gou moontlik deeglik ondersoek en verslag daaroor uitbring".

Ek wil derhalwe daarvoor pleit dat 'n permanente organisasie deur die Staat ingestel word vir die versameling van inligting oor die voedingspeil van alle bevolkingsgroepe. Aanvanklik hoef hierdie werk slegs die versameling en evaluering van reeds beskikbare inligting, byvoorbeeld sterftesyfers en inligting oor die nasionale voedselvoorrade, in te sluit, maar die uitbreiding en die verdere 
verwerking van sulke gegewens sal in baie gevalle ook wenslik wees. Ook sal so 'n program die uitvoer van voeding- en kliniese opnames in verskillende gedeeltes van die land op 'n voortdurende roetinebasis deur die betrokke organisasies insluit. Slegs op hierdie manier kan die Staat se voedingsbeleid en voedingsvoorligting op 'n gesonde, weloorwoë en realistiese basis geskei word.

(b) Voorligtingsprogram in voeding en higiëne: Hoewel daar deur die Departement van Landboutegniese Dienste 'n voortreflike voedingsvoorligtingsdiens vir hoofsaaklik die Blanke reeds jarelank funksioneer, is dit ons mening dat dit aansienlik uitgebrei moet word, veral na die ander bevolkingsgroepe.

Aangesien swak diëte nie altyd aan gebrek aan inkomste te wyte is nie, en voedingsgebreke dikwels nou verwant is aan lae higiëniese standaarde, word aanbeveel dat meer aandag gewy word aan voorligting insake voeding en higiëne, veral onder die Nie-blankes en in hul eie tale. Vir die voorkoming van kwashiorkor sal 'n opvoedkundige program onder Nie-blanke moeders van groot waarde wees, aangesien die onkunde van die moeder in verband met kindervoeding en -sorg as 'n belangrike faktor in die etiologie van die siekte beskou word.

\section{Voedingsprobleme van die blankes}

Die belangrikste voedingsprobleem van die blanke in die Republiek van Suid-Afrika is oorvoeding, wat herlei kan word na 'n oormatige inname van voedsel - ryk aan vette en proteïen - wat die koolhidraat- en vetmetabolisme versteur en veroorsaak dat die blanke SuidAfrikaners ' $n$ buitengewoon hoë insidensie van aterosklerose (hart-, hartvat- en verwante siektes) toon - trouens van die hoogste ter wêreld. Hierdie is 'n dodelike sens wat drasties onder die mees bevoegde mannekrag van clie land maai, en sterfgevalle hieraan neem in die R.S.A. ernstige afmetings aan.

Die N.Voed.N.I. is intensief gemoeid met 'n projek oor hierdie onderwerp. Dié studie het reeds baie interes- 
sante en belangrike gegewens opgelewer. Die uitgangspunt was om 'n studic te maak van koolhidraat- en vetmetabolisme, en daar is gevind dat waar jong Blanke mans en vroue, Blanke vroue bo 30 jaar en Bantoemans bo 30 jaar koolhidrate nog normaal metaboliseer en die bloedpatroon normaal is t.o.v. vetfraksies, ' $n$ aansienlike persentasie van Blanke mans bo 30 jaar reeds afwykings toon. Hierdie afwykings word aangedui deur abnormale verbranding van koolhidrate, soos vasgestel word deur (i) die suikertoleransietoets en (ii) die abnormaal hoë totale vetsuurinhoud en lae onversadigde vetsuurinhoud van die bloedserum. Van koronêre trombose-pasiënte wat ondersoek is, was meer as 80 persent abnormaal.

'n Groep van 19 pasiënte wat vrywilliglik as proefkonyne opgetree het, is op 'n lae kalorie-lae-vet-dieet geplaas en periodiek ondersoek. Besonder belowend is die feit dat hulle al almal of tot normale koolhidraat- en vetmetabolisme en bloedvetpatroon teruggekeer het òf groot verbetering getoon het. So byvoorbeeld het hul gemidclelde serumvetsuurkonsentrasie van $517 \mathrm{mg}$ persent gedaal tot 319 na 8 tot 12 maande op die dieet.

Die hipotese wat hieruit voortvloei is dat oorbelading van die liggaam met 'n ryk dieet, te veel kalorieë en veral te veel vetkalorieë lei tot 'n versteurde metabolisme. Die finale, onweerlegbare bewys dat hierdie versteurde metabolisme lei tot hartvatsiektes - insluitende koronêre trombose - sal moeilik wees om te vind, maar die „omstandigheidsgetuienis" is sterk.

Indien dit so is, dan is die bevinding dat die versteuring nie permanent is nie maar wel omkeerbaar, en dat die metaboliese prosesse onder 'n beperkende dieet weer tot normaal terugkeer, baie belangrik en ag behoort daarop geslaan te word deur dié persone wat al die ouderdom bereik het waar hartvatsiektes soveel slagoffers eis.

29 Mei 1963.

F. W. Quass.

Pretoria.

\section{Literatuurverwysings:}

1) F. W. Quass: „Voeding en die Staat”, Handelinge van Voedingvereniging van Suidelike Afrika, Vol. 3, 1962, pp. 117-126.

2) F. W. Ouass: "General Aspects of Nutrition in South Africa". 
Annual Proceedings of the Associated Scientific and Technical Societies of S.A., 1959/60, pp. 43-59.

3) V.L.O.: „Statistics of Hunger", Voedsel- en Landbouorganisasie, Rome, 1962.

4) Wyndham et al: „The Influence of a Stable Diet and Regular Work on Body Weight and Capacity for Exercise in African Mine Recruits", Ergonomics, Vol. 5, nr. 5, pp. 435-444, Julie 1962.

5) Ward et al: „Weight and Weight Changes of Native Mine Recruits", T.F.L. Verslag nr. 11/61, T. \& O.V.S. Kamer van Mynwese, 23, pp. 1961.

6) Holman, W. I. M.: "Organization and Co-ordination of Food and Nutrition Services in South Africa", Handelinge van Voedingvereniging van Suidelike Afrika, Vol. 3, 1962, pp. 52-60. 